\title{
Methylotenera mobilis gen. nov., sp. nov., an obligately methylamine-utilizing bacterium within the family Methylophilaceae
}

\author{
Marina G. Kalyuzhnaya, ${ }^{1}$ Sarah Bowerman, ${ }^{2}$ Jimmie C. Lara, ${ }^{3}$ \\ Mary E. Lidstrom ${ }^{1,3}$ and Ludmila Chistoserdova ${ }^{1}$ \\ ${ }^{1,2,3}$ Department of Chemical Engineering ${ }^{1}$, Department of Biology ${ }^{2}$ and Department of
Microbiology ${ }^{3}$, University of Washington, Seattle, WA 98195, USA
}

Ludmila Chistoserdova

milachis@u.washington.edu

\begin{abstract}
A novel obligate methylamine utilizer (strain $\mathrm{JLW}^{\top}$ ), isolated from Lake Washington sediment, was characterized taxonomically. The isolate was an aerobic, Gram-negative bacterium. Cells were rod-shaped and motile by means of a single flagellum. Reproduction was by binary fission and no resting bodies were formed. Growth was observed within a $\mathrm{pH}$ range of 5-8.5, with optimum growth at $\mathrm{pH} 7 \cdot 5$. It utilized methylamine as a single source of energy, carbon and nitrogen. Methylamine was oxidized via methylamine dehydrogenase and formaldehyde was assimilated via the ribulose monophosphate cycle. The cellular fatty acid profile was dominated by $\mathrm{C}_{16: 0} \omega 7 c$ and $\mathrm{C}_{16: 0}$ and the major phospholipid was phosphatidylethanolamine. The DNA G $+\mathrm{C}$ content was $54 \mathrm{~mol} \%$. 16S rRNA gene sequence analysis indicated that the new isolate was closely related (97-98\% similarity) to a broad group of sequences from uncultured or uncharacterized Betaproteobacteria, but only distantly related (93-96\% similarity) to known methylotrophs of the family Methylophilaceae. Strain JLW8 ${ }^{\top}\left(=\right.$ ATCC BAA $-1282^{\top}=$ DSM $\left.17540^{\top}\right)$ is proposed as the type strain of a novel species in a new genus within the family Methylophilaceae, Methylotenera mobilis gen. nov., sp. nov.
\end{abstract}

Methylotrophs are microbes capable of utilizing single $\mathrm{C}_{1}$ compounds as sole sources of energy and carbon. Methylotrophic ability is especially widespread within the Proteobacteria, encompassing the alpha, beta and gamma subdivisions (Anthony, 1982; Hanson \& Hanson, 1996). Methylotrophs of the Alphaproteobacteria include four genera of obligate and restricted facultative methanotrophs (Methylosinus, Methylocystis, Methylocapsa and Methylocella) and a broad group (over ten genera) of facultatively methylotrophic bacteria (Methylobacterium, Methylopila, Hyphomicrobium, etc.). Methylotrophs of the Gammaproteobacteria are represented by nine genera of obligately methanotrophic bacteria (Methylomonas, Methylococcus, Methylothermus, Methylomicrobium, Methylosphaera, Methylobacter, Methylocaldum, Methylohalobius and Methylosarcina) and three genera of non-methanotrophic methylotrophic bacteria (Methylophaga, Marinobacterium and Pseudomonas). Betaproteobacterial methylotrophs are represented by three genera (Methylobacillus, Methylophilus and Methylovorus) within the family Methylophilaceae and so far by a single genus (Methylibium) within the Burkholderiales (Nakatsu et al.,

Abbreviation: RuMP, ribulose monophosphate.

The GenBank/EMBL/DDBJ accession number for the 16S rRNA gene sequence of strain $\mathrm{JLW8}^{\top}$ is DQ287786.
2006). 16S rRNA gene sequences with close similarity to those of methylotrophs of the family Methylophilaceae have been detected in a variety of ecosystems; a few representative strains have been cultured but not formally characterized (Connon \& Giovannoni, 2002; Lueders et al., 2004; De Marco et al., 2004; Fuchs et al., 2005; Gich et al., 2005). In this study we describe a novel betaproteobacterial obligate methylotroph isolated from lake sediment. Based on $16 \mathrm{~S}$ rRNA gene sequence analysis, this strain is shown to be more closely related to uncultured or unidentified Betaproteobacteria than to known betaproteobacterial methylotrophs. We propose that this new isolate represents a novel species of a new genus within the family Methylophilaceae.

Strain $\mathrm{JLW8}^{\mathrm{T}}$ was isolated from sediment recovered from Lake Washington, Washington State, USA, after enrichment in a basal salts medium (Harder et al., 1973) diluted five-fold and supplemented with $0 \cdot 1 \%$ methylamine as described previously (Miller et al., 2005). The purity of the culture was monitored by microscopy, by $16 \mathrm{~S}$ rRNA gene sequence amplification and analysis, and by testing the ability to grow on tryptone-glucose-yeast extract (TGY; Murray, 1992), Luria-Bertani (LB; Sambrook et al., 1989) or Nutrient (Difco) media. Characterization of the ultrastructural, phenotypic and genotypic properties of strain $\mathrm{JLW}^{\mathrm{T}}$ was performed as described previously (Miller et al., 2005). 
Transmission election microscopy was performed as described previously (Kalyuzhnaya et al., 2005). Negatively stained preparations and thin sections were viewed by using a 1200 Ex II transmission electron microscope (JEOL) at an operating voltage of $80 \mathrm{kV}$. The strain was routinely grown in the basal salts medium supplemented with $0 \cdot 1$ or $0 \cdot 2 \%$ methylamine. Cells were stored in the same basal salts medium supplemented with $10 \% \mathrm{DMSO}$, at $-80^{\circ} \mathrm{C}$. $16 \mathrm{~S}$ rRNA gene sequences were aligned using the CLUSTALW program (Higgins et al., 1996). Phylogenetic analysis was carried out using the PHYLIP package (Felsenstein, 2003). The distance method was employed, and 100 bootstrap analyses were performed.

Colonies of strain $\mathrm{JLW} 8^{\mathrm{T}}$ were cream to light brown and $1-2 \mathrm{~mm}$ in diameter when grown at $30^{\circ} \mathrm{C}$ for $4-7$ days. No pigmentation was observed when cells were grown in liquid culture. Cells did not form aggregates in liquid culture. Microscopy revealed that cells were rod-shaped, $0 \cdot 6-1 \cdot 2 \times$ $0 \cdot 3-0 \cdot 4 \mu \mathrm{m}$, occurred singly, were motile by means of a single polar flagellum (Fig. 1) and had a Gram-negative cell wall structure. Some cells possessed cell wall extrusions, or 'prostheca'-like structures. Cells reproduced by binary fission and did not form resting bodies. Strain JLW8 ${ }^{\mathrm{T}}$ utilized only methylamine as a growth substrate, but not methanol, formate, dimethylamine, trimethylamine, organic acids, sugars, amino acids, $\mathrm{C}_{2}-\mathrm{C}_{6}$ alcohols or methane. No growth occurred on TGY, LB or Nutrient media. The optimal concentration of methylamine required for growth was tested using a Bioscreen $C(\mathrm{MBR})$ plate reader at the following concentrations $(\mathrm{w} / \mathrm{v}): 0,0 \cdot 01,0 \cdot 05$, $0 \cdot 1,0 \cdot 2,0 \cdot 3,0 \cdot 4,0 \cdot 5,1$ and $2 \%$. Growth occurred at $0 \cdot 01-0 \cdot 5 \%$ methylamine with an optimum at $0 \cdot 05-0 \cdot 1 \%$. The specific growth rate in liquid basal medium supplemented with $0 \cdot 1 \%$ methylamine was $0 \cdot 134 \mathrm{~h}^{-1}$. Strain $\mathrm{JLW} 8^{\mathrm{T}}$ grew in the temperature range $10-34^{\circ} \mathrm{C}$, and a $\mathrm{pH}$ range $5-8 \cdot 5$, with optimal growth occurring at $30^{\circ} \mathrm{C}$ and a $\mathrm{pH}$ of $7 \cdot 5$. Elimination of ammonium from the basal mineral medium did not affect growth, indicating that methylamine could serve as a nitrogen source. However, replacing ammonium salts with nitrate salts $(0 \cdot 1 \%)$ resulted in growth inhibition. The test for nitrate reduction was negative. Because strain $\mathrm{JLW} 8^{\mathrm{T}}$ was restricted to growth using methylamine as a single source of carbon, we were not able to verify its ability to grow without a nitrogen source. However, a PCR amplification test using primers specific for the nifH gene (Zehr \& McReynolds, 1989) was negative, suggesting that the strain was unable to utilize $\mathrm{N}_{2}$. No growth was observed at concentrations of $\mathrm{NaCl}$ above $0 \cdot 1 \%$, SDS concentrations above $0 \cdot 001 \%$ or $\mathrm{H}_{2} \mathrm{O}_{2}$ concentrations above $0.00003 \%$. Tests for oxidase and catalase were positive. Urease activity was not detected. Cells were not resistant to desiccation, heating to $70^{\circ} \mathrm{C}$ for $5 \mathrm{~min}$ or to $60^{\circ} \mathrm{C}$ for $10 \mathrm{~min}$, and growth was observed after heating to $60{ }^{\circ} \mathrm{C}$ for $5 \mathrm{~min}$.

Sensitivity to antibiotics was examined in liquid cultures. The following antibiotics were tested $\left(\mu \mathrm{g} \mathrm{ml}^{-1}\right)$ : ampicillin

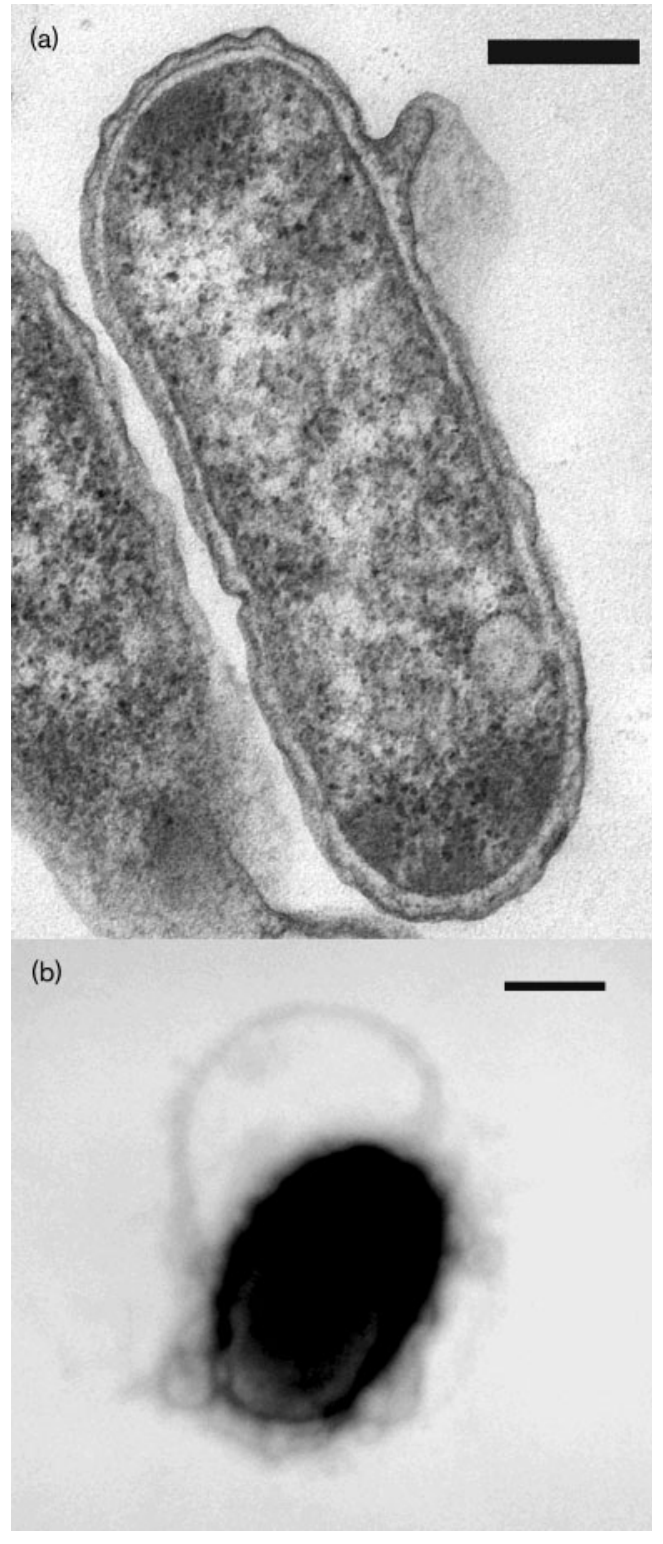

Fig. 1. Electron micrographs of thin-sectioned cells of strain $\mathrm{JLW}^{\top}$ showing details of the cell wall (a) and a negatively stained cell (b). Bars, $0.2 \mu \mathrm{m}$.

(30), chloramphenicol (10), gramicidin (10), kanamycin (30), nalidixic acid (30), penicillin (30), tetracycline (10), rifampicin (30), rifomycin (10) and streptomycin (10). The effect of antibiotics on cell growth was assessed after 1 week. No growth was observed in the presence of gramicidin, kanamycin or tetracycline, whereas chloramphenicol, ampicillin, nalidixic acid and streptomycin inhibited growth.

Activities of key enzymes for methylotrophy were measured in cell-free extracts of strain $\mathrm{JLW}^{\mathrm{T}}$, as described by Kalyuzhnaya et al. (2005). Tests for methylamine dehydrogenase were positive $\left[23 \pm 5 \mathrm{nmol} \mathrm{\textrm {min } ^ { - 1 }}(\mathrm{mg} \text { protein })^{-1}\right.$; $n=3$ ], suggesting its role in methylamine oxidation. Tests 
for methanol dehydrogenase activity were negative. Accordingly, no PCR product with primers specific for the mxaF gene (McDonald \& Murrell, 1997) was obtained. Combined activities of the key enzymes of the ribulose monophosphate (RuMP) cycle, hexulose phosphate synthase and 6-phospho-3-hexuloisomerase, were detected $\left[13 \pm 3 \mathrm{nmol} \mathrm{min}{ }^{-1}(\mathrm{mg} \text { protein })^{-1} ; n=3\right]$, indicating that the RuMP cycle was operational, whereas no activities of key enzymes of the serine cycle, hydroxypyruvate reductase and serine-glyoxylate aminotransferase, were detected. No activities of formaldehyde dehydrogenase (measured with or without glutathione) or formate dehydrogenase (measured with NAD) were detected.

Cellular phospholipid fatty acid analysis was performed by Microbial Insights (http://www.microbe.com). The fatty acid profile was dominated by $\mathrm{C}_{16: 1} \omega 7 c(66 \%)$ and $\mathrm{C}_{16: 0}$ (32\%), which is typical of the known obligate or restricted facultative methylotrophs within the Betaproteobacteria. However, strain JLW ${ }^{\mathrm{T}}$ did not contain the $\mathrm{C}_{16: 1} \omega 7 t$ isomer found so far in all representatives of the Methylophilaceae. The major phospholipid, as detected by TLC (Findlay \& Evans, 1987), was phosphatidylethanolamine ( $>80 \%$ of the total phospholipid fraction).

The $\mathrm{G}+\mathrm{C}$ content of the genomic DNA was $54 \cdot 3 \pm$ $0 \cdot 3 \mathrm{~mol} \%(n=3)$. Analysis of a nearly complete sequence of the $16 \mathrm{~S}$ rRNA gene indicated that strain $\mathrm{JLW} 8^{\mathrm{T}}$ was only distantly related to known methylotrophic bacteria of the family Methylophilaceae, sharing 94.3-95.6\% similarity with representatives of the genus Methylophilus and $93 \cdot 1-94 \cdot 8 \%$ similarity with representatives of the genera Methylovorus and Methylobacillus. However, it was more closely related (97-98\% similarity) to environmental $16 \mathrm{~S}$ rRNA gene sequences and to the sequence of the uncharacterized strain HTCC349 isolated from a trichloroethene- and dichloroethene-contaminated aquifer (Connon et al., 2005). Phylogenetic analysis revealed that the $16 \mathrm{~S}$ rRNA gene sequence of strain $\mathrm{JLW}^{\mathrm{T}}$ grouped with environmental sequences and the sequence of strain HTCC 349, and that these were separated from the sequences of species representing the genera Methylobacillus, Methylovorus and Methylophilus (Fig. 2).

All representatives of the Methylophilaceae described thus far have been reported to be obligate or restricted facultative methylotrophs capable of utilizing methanol as a sole source of carbon and energy and possessing methanol dehydrogenase activity (Jenkins \& Jones, 1987; Doronina et al., 2004, 2005a). Strain JLW $8^{\mathrm{T}}$ is the first example of a representative of the Methylophilaceae lacking the ability to grow on methanol and restricted to methylamine as a single $C_{1}$ substrate. Based on this feature as well as other distinctive features such as the lack of $\mathrm{C}_{16: 1} \omega 7 t$ fatty acid (Table 1 ) and low level of $16 \mathrm{~S}$ rRNA gene sequence similarity with members of the genera Methylophilus, Methylobacillus

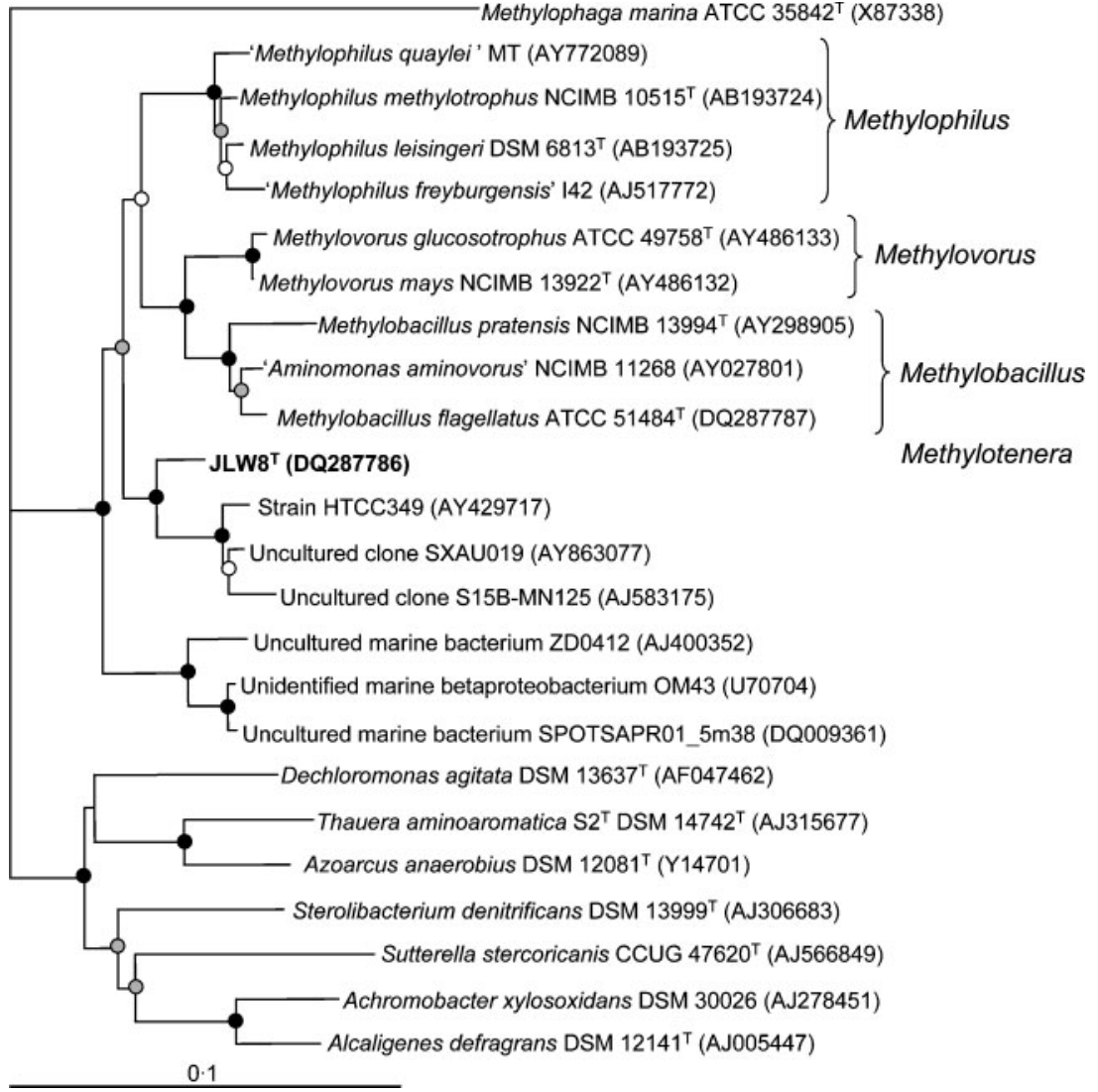

Fig. 2. Phylogenetic tree showing the relationship of strain $\mathrm{JLW}^{\top}$ to representatives of the Methylophilaceae and to other members of the Betaproteobacteria, based on 16S rRNA gene sequences. Filled circles indicate bootstrap support over $95 \%$, shaded circles bootstrap support over $70 \%$ and open circles bootstrap support over $50 \%$. Strain collection accession numbers (where available) and GenBank accession numbers (in parentheses) are shown. Bar, $10 \%$ sequence divergence. 
Table 1. Differential characteristics of strain $\mathrm{JLW}^{\top}$ and related methylotrophic bacteria of the family Methylophilaceae

Taxa: 1, strain JLW8 ${ }^{\mathrm{T}}$; 2, Methylophilus (data from Ikemoto et al., 1978; Doronina et al., 2005b); 3, Methylovorus (Doronina et al., 2005a; Govorukhina \& Trotsenko, 1991); 4, Methylobacillus (Govorukhina \& Trotsenko, 1991; Govorukhina et al., 1987; Doronina et al., 2004). +, Positive; +/-, variable; -, negative.

\begin{tabular}{|lcccc|}
\hline Characteristic & $\mathbf{1}$ & $\mathbf{2}$ & $\mathbf{3}$ & $\mathbf{4}$ \\
\hline Flagellation & + & $+/-$ & + & + \\
Growth using: & & & & \\
$\quad$ Methanol & - & + & + & + \\
$\quad$ Methylamine & + & $+/-$ & $+/-$ & $+/-$ \\
$\quad$ Glucose & - & + & - & $+/-$ \\
Optimum growth & 30 & $25-37$ & $35-40$ & $29-42$ \\
temperature $\left({ }^{\circ} \mathrm{C}\right)$ & & & & \\
Optimum pH & $7 \cdot 5$ & $6 \cdot 5-7 \cdot 5$ & $7 \cdot 0-7 \cdot 5$ & $6 \cdot 5-7 \cdot 5$ \\
Methanol dehydrogenase & - & + & + & + \\
Methylamine dehydrogenase & + & $+/-$ & $+/-$ & $+/-$ \\
RuMP pathway & + & + & + & + \\
Fatty acid content $(\%):$ & & & & \\
$\mathrm{C}_{16: 0}$ & 32 & $32-48$ & $47-49$ & $41-43$ \\
$\mathrm{C}_{16: 1} \omega 7 c$ & 66 & $46-53$ & $32-35$ & $32-36$ \\
$\mathrm{C}_{16: 1} \omega 7 t$ & 0 & $4-12$ & $2-3$ & $3-8$ \\
$\mathrm{C}_{18: 0}$ & $0 \cdot 3$ & $0 \cdot 6-4$ & $0 \cdot 6-0 \cdot 7$ & $0 \cdot 7-1 \cdot 2$ \\
$\mathrm{C}_{18: 1} \omega 7 c$ & $0 \cdot 7$ & $0 \cdot 7-2$ & $1-2$ & 5 \\
DNA G $+\mathrm{C}$ content $($ mol\%) & 54 & $50-53$ & $56-58$ & $53-62$ \\
& & & & \\
\hline
\end{tabular}

and Methylovorus, strain $\mathrm{JLW}^{\mathrm{T}}$ is proposed as the type strain of a novel species in a new genus within the family Methylophilaceae, Methylotenera mobilis gen. nov., sp. nov.

16S rRNA gene sequences closely related to that of strain $\mathrm{JLW} 8^{\mathrm{T}}$ have been amplified from a variety of environments, such as wastewater treatment plants, contaminated aquifers, mining waste and sedimentary rocks (based on descriptions of the sequence sources in the NCBI database), pointing to the widespread distribution and potential ecologically important function of this group of organisms.

\section{Description of Methylotenera gen. nov.}

Methylotenera (Me.thy.lo.ten'er.a. Gr. n. methyl the methyl group; L. fem. adj. tenera delicate; N.L. fem. n. Methylotenera delicate methyl-utilizing organism).

Gram-negative rods, motile by means of a single flagellum. Do not form resting bodies. Multiply by binary fission. Do not grow in TGY, LB or Nutrient media. Utilize methylamine as a single source of carbon, energy and nitrogen, but do not utilize methanol. Tests for urease and nitrate reduction are negative. Tests for catalase and oxidase are positive. Nitrates inhibit growth. Oxidize methylamine via methylamine dehydrogenase and assimilate $C_{1}$ units via the RuMP pathway. Major fatty acids are $\mathrm{C}_{16: 1} \omega 7 c$ and
$\mathrm{C}_{16: 0}$. The major phospholipid is phosphatidylethanolamine. The $\mathrm{G}+\mathrm{C}$ content of the DNA is $54 \cdot 3 \mathrm{~mol} \%$. The type species is Methylotenera mobilis.

\section{Description of Methylotenera mobilis sp. nov.}

Methylotenera mobilis (mo'bi.lis. L. fem. adj. mobilis motile).

General characteristics are as for the genus. Obligate methylamine utilizer. Grows at $\mathrm{pH} 5-8 \cdot 5$, with an optimum at $\mathrm{pH} 7 \cdot 5$. Temperature optimum is $30^{\circ} \mathrm{C}$. No cell aggregation in liquid medium. Cells are $0.6-1 \cdot 2 \times$ $0 \cdot 3-0 \cdot 4 \mu \mathrm{m}$ in size and occur singly. Cells are not resistant to desiccation or heating $\left(70{ }^{\circ} \mathrm{C}\right.$ for $\left.5 \mathrm{~min}\right)$.

The type strain, $\mathrm{JLW}^{\mathrm{T}}{ }^{\mathrm{N}}\left(=\mathrm{ATCC}\right.$ BAA- $1282^{\mathrm{T}}=\mathrm{DSM}$ $\left.17540^{\mathrm{T}}\right)$, was isolated from freshwater Lake Washington (USA).

\section{Acknowledgements}

This research was supported by a grant (MCB-0131957) from the NSF Microbial Observatories Program.

\section{References}

Anthony, C. (1982). The Biochemistry of Methylotrophs. London: Academic Press.

Connon, S. A. \& Giovannoni, S. J. (2002). High-throughput methods for culturing microorganisms in very-low-nutrient media yield diverse new marine isolates. Appl Environ Microbiol 68, 3878-3885.

Connon, S. A., Tovanabootr, A., Dolan, M., Vergin, K., Giovannoni, S. J. \& Semprini, L. (2005). Bacterial community composition determined by culture-independent and -dependent methods during propane-stimulated bioremediation in trichloroethene-contaminated groundwater. Environ Microbiol 7, 165-178.

De Marco, P., Pacheco, C. C., Figueiredo, A. R. \& Moradas-Ferreira, P. (2004). Novel pollutant-resistant methylotrophic bacteria for use in bioremediation. FEMS Microbiol Lett 234, 75-80.

Doronina, N. V., Trotsenko, Y. A., Kolganova, T. V., Tourova, T. P. \& Salkinoja-Salonen, M. S. (2004). Methylobacillus pratensis sp. nov., a novel non-pigmented, aerobic, obligately methylotrophic bacterium isolated from meadow grass. Int J Syst Evol Microbiol 54, 1453-1457.

Doronina, N. V., Ivanova, E. G. \& Trotsenko, Y. A. (2005a). Phylogenetic position and emended description of the genus Methylovorus. Int J Syst Evol Microbiol 55, 903-906.

Doronina, N. V., Ivanova, E. G., Trotsenko, Y. A., Pshenichnikova, A., Kalinina, E. \& Shvets, V. (2005b). Methylophilus quaylei sp. nov., a new aerobic obligately methylotrophic bacterium. Syst Appl Microbiol 28, 303-309.

Felsenstein, J. (2003). Inferring Phylogenies. Sunderland, MA: Sinauer Associates.

Findlay, J. B. C. \& Evans, W. H. (1987). Biological Membranes: A Practical Approach. Washington, DC: IRL Press.

Fuchs, B. M., Woebken, D., Zubkov, M. V., Burkill, P. \& Amann, R. (2005). Molecular identification of picoplankton populations in contrasting waters of the Arabian Sea. Aquat Microb Ecol 39, $145-157$. 
Gich, F., Schubert, K., Bruns, A., Hoffelner, H. \& Overmann, J. (2005). Specific detection, isolation, and characterization of selected, previously uncultured members of the freshwater bacterioplankton community. Appl Environ Microbiol 71, 5908-5919.

Govorukhina, N. I. \& Trotsenko, Y. A. (1991). Methylovorus, a new genus of restricted facultatively methylotrophic bacteria. Int J Syst Bacteriol 41, 158-162.

Govorukhina, N. I., Kletsova, L. V., Tsygankov, Y. D., Trotsenko, Y. A. \& Netrusov, A. I. (1987). Characteristics of a new obligate methylotrophous bacterium. Mikrobiologiia 56, 849-854.

Hanson, R. S. \& Hanson, T. E. (1996). Methanotrophic bacteria. Microbiol Rev 60, 437-471.

Harder, W., Attwood, M. \& Quayele, J. R. (1973). Methanol assimilation by Hyphomicrobium spp. J Gen Microbiol 78, 155-163.

Higgins, D. G., Thompson, J. D. \& Gibson, T. J. (1996). Using CLUSTAL for multiple sequence alignments. Methods Enzymol 266, 383-402.

Ikemoto, S., Katoh, K. \& Komagata, K. (1978). Cellular fatty acid composition in methanol-utilizing bacteria. J Gen Appl Microbiol 24, 41-49.

Jenkins, O. \& Jones, D. (1987). Taxonomic studies on some Gramnegative methylotrophic bacteria. J Gen Microbiol 133, 453-473.

Kalyuzhnaya, M. G., Stolyar, S. M., Auman, A. J., Lara, J. C., Lidstrom, M. E. \& Chistoserdova, L. (2005). Methylosarcina lacus sp. nov., a methanotroph from Lake Washington, Seattle, USA, and emended description of the genus Methylosarcina. Int J Syst Evol Microbiol 55, 2345-2350.
Lueders, T., Wagner, B., Claus, P. \& Friedrich, M. W. (2004). Stable isotope probing of rRNA and DNA reveals a dynamic methylotroph community and trophic interactions with fungi and protozoa in oxic rice field soil. Environ Microbiol 6, 60-72.

McDonald, I. R. \& Murrell, J. C. (1997). The methanol dehydrogenase structural gene $m x a F$ and its use as a functional gene probe for methanotrophs and methylotrophs. Appl Environ Microbiol 63, 32183224.

Miller, J. A., Kalyuzhnaya, M. G., Noyes, E., Lara, J. C., Lidstrom, M. E. \& Chistoserdova, L. (2005). Labrys methylaminiphilus sp. nov., a novel facultatively methylotrophic bacterium from a freshwater lake sediment. Int J Syst Evol Microbiol 55, 1247-1253.

Murray, R. G. E. (1992). The family Deinococcaceae. In The Prokaryotes, 2nd edn, pp. 3732-3744. Edited by A. Balow, H. G. Trüper, M. Dworkin, W. Harder \& K.-H. Schleifer. New York: Springer.

Nakatsu, C. H., Hristova, K., Hanada, S., Meng, X.-Y., Hanson, J. R., Scow, K. M. \& Kamagata, Y. (2006). Methylibium petroleiphilum gen. nov., sp. nov., a novel methyl tert-butyl ether-degrading methylotroph of the Betaproteobacteria. Int J Syst Evol Microbiol 56, 983-989.

Sambrook, J., Fritsch, E. F. \& Maniatis, T. (1989). Molecular Cloning: A Laboratory Manual, 2nd edn. Cold Spring Harbor, NY: Cold Spring Harbor Laboratory.

Zehr, J. P. \& McReynolds, L. A. (1989). Use of degenerate oligonucleotides for amplification of the nifH gene from the marine cyanobacterium Trichodesmium thiebautii. Appl Environ Microbiol 55, 2522-2526. 